\title{
THE WRITTEN WORD IN THE ARAGONESE RECONQUISTA*
}

\author{
William C. STALLS
}

Under the influences of linguistic theory and social history, medievalists have reevaluated the role of the written word in the Middle Ages. In line with these influences, this reevaluation emphasizes less the actual literacy of persons and more the functions of the written word, to determine its importance in medieval society '. In other words, the state of literacy in medieval society is no longer the chief focus; the uses of writing are. An excellent opportunity to study the function of the written.word in a medieval society comes from the Iberian kingdom of Aragon; and the best opportunity in this realm's history can be found in the glory years of the Aragonese Reconquista during the reigns of Pedro I (1094-1104) and Alfonso I (1104-1134). Under the rule of these two brothers, the Aragonese gobbled up large amounts of territory from Spanish Islam ${ }^{2}$. In turn this great acquisition of land created an active land market in

- This article is based on my paper presented at the 103rd Annual Meeting of the American Historical Association, Cincinnati, Ohio, 28 December 1988.

' Some of the more important books in this respect are Brian STOCK, The Implications of Literacy: Written Language and Models of Interpretation in the Eleventh and Twelfth Centuries, Princeton, 1983; Rosamond MCKITTERICK, The Carolingians and the Written Word, Cambridge University Press, 1989; and idem, ed., The Uses of Literacy in Early Medieval Europe, Cambridge University Press, 1990. Citing, for example, penitentials, Stock speaks of woral discoursen operating within the context of writing (pp. 77-9). Also consider McKitterick's contention, as opposed to Stock, that in the early Middle Ages the written word had important uses, something usually considered true only for the High Middle Ages.

For another example of emphasis on function, see Thomas Noble's essay «Literacy and Papal Government in Late Antiquity and the Early Middle Ages, $w$ in MCKITTERICK, Uses, esp. pp. 83,108 . Here Noble describes the practical uses of literacy in papal government.

2 The preeminent authority on medieval Aragon, José María Lacarra, estimated that the Aragonese acquired some 34,000 square kilometers of land. See his Aragón en el pasado, 2nd ed., Madrid, 1977, p. 61. 
which the written word in the form of the charter flourished, the basic tool by which land and other property transactions were enacted.

This period is also advantageous to study for two other reasons. Under the sanction of royal authority, the public notary, with its fides publica, had not yet reappeared in Aragon. Charters during the eleventh and twelfth centuries, in the view of traditional diplomatics, were not yet dispositive--their chief function remained that of witness lists '. This assumption about the use of charters will be tested against Aragonese practices. Another important point also ought to be considered. Aragon's union with Catalunya that created the Crown of Aragon did not occur until 1137. Consequently, Aragonese diplomatics during Pedro's and Alfonso's reign were not yet subject to Catalan influences. With these considerations in mind, let us now examine the use of charters in medieval Aragon.

The field of diplomatics has distinguished two categories of charters in the Middle Ages: public, that is, all royal and papal charters; and private, all non-royal and non-papal charters ${ }^{4}$. The key development in the history of the private charter has been traditionally seen as its loss of dispositive force after the Germanic invasions ended Roman rule in the West. Charters were at best only probative and served merely to record witnesses of property transactions. They did not constitute a legal document that transferred property; rather property was alienated in a ceremony conducted orally, with the exchange of some object between two parties actually transferring property. This view has been challenged, however, with recent scholarship holding that the charter validated property transactions'.

As for the Iberian Peninsula, the charter continued to be commonly used after the end of Roman rule because of the Visigothic Law Code that embraced both the probative worth of a charter and witnesses to validate a property transaction ${ }^{\circ}$. Although less affected by the Visigoths than other parts of the

+ On this point, see n. 5 below. On the reappearance of the public notary established by the king or by municipal governments with royal authorization to do so, see José BoNO, Historia del derecho notarial espantol, 2 vols. [I:1 and I:2], Madrid, 1979ff, I:2, Pp. 1201.

4 A. de Boùard, Manuel de diplomatique: Franşaise et pontificale. Vol. 2: L'acte privé, Paris, 1948, pp. 10-11.

' On the private charter's lack of dispositive force in the early Middle Ages, see STOCK, pp. 43-45, and BOUARD, pp. 43-50. On Germanic custom of property transfers and the small role of charters in this custom, see Peter CLASSEN, Urkunderwesen im Friben Mittelalter, in Recht und Schrift im Mittelalter, ed. Peter ClASSEN, Sigmaringen, 1977, pp. 36- 40. For the reevaluation of the charter's legal significance, see MCKITTERICK, Carolingian, pp. 62, 98.

6 On the influence of the Code, see BONO, I:1, pp. 80-81; and Roger Collins, Visigothic law and regional custom in disputes in early medieval Spain, in "The Settlement of 
Iberian Peninsula, Aragon still reflected the general Iberian practice of using charters for property transactions. Certainly by the eleventh century the charter had come to play a major role in property transactions in Aragon, as we shall shortly see. Before the thirteenth century reappearance of the public notary with royal authority to legalize documents, charters in Aragon were produced by professional scribes, either clerical or secular. Clerical scribes, easily distinguished by such titles as presbiter or capellanus in charters, seem especially prominent and were especially needed to record property rights. For example, monasteries or cathedrals required scribes to draw up documents for property records and called on their own members for this task '. Commoner and noble alike counted on these clerical or lay scribes to produce charters, for even the great nobility of Aragon lacked chanceries ${ }^{8}$. With Aragonese expansion from the Pyrenees into the Ebro River Valley, professional lay scribes especially proliferated; but where and how these scribes received their training is a mystery. Since evidence for the training of these scribes is lacking, it must be assumed that, as in other parts of the Iberian Peninsula, scribal training was undertaken in the scriptoria of monasteries, the bishop's court, or the cathedral school. ${ }^{\text {s }}$

No typology has been established for the private charters that Aragonese scribes produced. Charters like those of Aragon can be classified according to the categories determined by scribes themselves or by the modern student of diplomatics ". In Aragon's case, we can let charters classify themselves, since in the notification of the corpus of charters, scribes usually described the type of transaction that the charter recorded. In turn the description of a transcription provides the categories with which to classify Aragonese charters: «This is the

Disputes in Early Medieval Europe", eds. Wendy DAviES and Paul FouraCre, Cambridge, 1986, p. 85. Collins (pp. 103-4) believes that Aragon and Navarre lagged behind the rest of the Iberian Peninsula in the use of charters and that the two areas were less influenced by the Code.

' Mariano AlONSO y LAMBÁn, Notas para el estudio del notariado de Aragón, "Anuario de derecho aragonés», V (1949-50), p. 387; Rosa RODRÍGUEZ TrONCOSO, Algunas consideraciones sobre los origenes del notariado en el alto Aragón, in «VIII Congreso de Historia de la Corona de Aragón. Crónica, ponencias y comunicaciones, 3: "Comunicaciones», Barcelona, 1962, pp. 250-1.

8 BONO, I: 1, p. 115.

"Ibid., pp. 158-9; AlONSO, p. 387.

10 Robert I. BURNS, Diplomatarium of the Crusader Kingdom of Valencia: The Registered Charters of Its Conqueror Jaume 1, 1257-1276. Vol. 1: Society and Documentation in Crusader Valencia, Princeton, 1985, p. 138. 
charter of division." "This is the charter of donation.» "2This is the charter of purchase." "13 "This is the charter of the authority of the pledge.» "This is the charter of the authority of the sale." " Sometimes the scribe would label his document a "writing" but still classify it according to function: "per hanc scripturam vendicionis. ${ }^{16}$ In short, these charter formulas describe the function of a charter, eg, to record a sale, and the different functions provide the categories of classification for Aragonese charters from the late eleventh and early twelfth centuries: sale, donation, purchase, pledge, and property divisions.

The common charter formulas just cited range chronologically from the late eleventh century to the early twelfth century, and geographically from Huesca to Zaragoza. The broad geographical and chronological usage of these formulas indicates a common training for Aragonese scribes. Other widespread formularies also indicate common scribal training, and in general Aragonese charters display similar diplomatic form, wherever their origin. This common format includes an explicit invocation, of which the most common forms are in nomine Dei, or in nomine sancte et individue Trinitatis: Patris ac Fillii et Spiritus Sancti. After this come the notification and disposition in the corpus of a charter, stating the names of the buyer and seller, their intentions, and the property being alienated. The following formula is typical: «I, Durán, sold my garden ... with its tower and trees ... to you, Sancho, bishop of Calahorra, for the price that we agreed on.» "In the final section of the corpus are listed the fidanzas (guarantors of the transaction) and witnesses. The date (almost always in the Spanish Era) and actum (place enacted) come in the final protocol, along with a list of the important lords of Aragon and their lordships, and bishops. Sometimes an important historical event in Aragon or for all Spain was also noted ${ }^{18}$. These notices function as a means to date a document; but they may have served other purposes as well. Historical writing in eleventh- and twelfth-

$"$ Documentos para el estudio de la Reconquista y repoblación del Valle del Ebro, ed. José María LACARRA, 2 vols., "Textos Medievales», 62, 63, Zaragoza, 1982, 1983, no. 130 (1126): "Hec est carta de particione." Hereafter cited as Documentos.

12 Ibid. no. 88 (1122): "Hec est carta donationis."

13 Colección diplomática de la catedral de Huesca, ed. Antonio DURAN GUDIOL, 2 vols., Fuentes para la historia del Pirineo, V, VI, Zaragoza, 1965, 1969, no. 60 (1094): «Hec est carta de compara." Hereafter cited as $\mathrm{CDH}$.

14 Documentos, no. 209 (1131): "Haec est carta de auctoritate de pignus."

1" $\mathrm{CDH}$, no. 110 (1112): "Hec est carta auctoritate venditionis."

16 Documentos, no. 134 (1126).

17 Ibid., no. 178 (1129): «Ego Duran vendidi meo orto ... cum sua torre ... tibi Sancio Calagorritano episcopo, in precio quanto conuenimus.»

18 For an example, see CDH, no. 72 (1098): «Facta carta ista era T.aC.aXXX.aVIa in mense augusto in illa obsidione de Calasanz." 
century Aragon is notable only for its paucity. Perhaps these short notices substituted for histories, serving as a type of historical annal in a land lacking a vibrant historical tradition ${ }^{19}$.

An important function of charters in Aragon was to record the customary practices of property transactions. A document from 1121 illustrates well how the written word recorded oral custom. At this time a Raol of Larrasoaña purchased a huerto (garden) in the Gallego River district of the city of Zaragoza. The property was purchased from Bonet of Bordel and his wife, Lucia. The disposition of the corpus explains exactly how the transaction was enacted: «I, Bonet of Bordel, and my wife, Lucia, surnamed Non Maís, sell to you, Raol of Larrasoaña, one huerto combined with a vineyard that is in the Gallego.» ${ }^{20}$ For his part Raol noted that he had paid for the property:
I, Raol of Larrasoaña, who bought this buerto
from you, Bonet of Bordel, in the presence of
your wife, Lucia, with the surname of Non Mais,
and of your sons, and the local residents ...
1 gave 45 solidi in Jacan currency to you for
that buerto. ${ }^{21}$

Later in the document Raol, through the scribe, reiterated that the money was received in the presence of all the local residents: «I gave those solidi, and you received them in the presence of all those local residents and witnesses and hearers." 22

The scribe of the charter precisely described the various steps of this

19 On the historiographical tradition of medieval Aragón, the best work is Lynn $\mathrm{H}$. Nelson's unpublished paper, Aragonese Historiography in the Eleventh and Twelfth Centuries, "101st Annual Meeting of the American Historical Association», 28 December 1986.

20) Documentos, no. 73 (1121): «Ego Bonet de Bordel et uxor mea Lucia super nomen Non Maís ... uendo tibi Raol de Arassunna uno orto misclato uinea quod est in Gallico." The verb here is in the singular, although Lucia is coupled to Bonet--and consequently the alienation of the property--by et. The Latin of Aragonese charters was wildly irregular; but the construction here of a singular verb linked to a plural subject (Bonet and Lucia) was probably based on the ablative of companion, a classical construction that found more popularity in medieval Latin. This construction is discussed in Maurilio PÉREZ GoNZÁlez, El latín de la cancillería castellana (1158-1214), Acta salmanticensia, Filosfía y letras, 163, Salamanca, 1985 , p. 125.

${ }^{21}$ Documentos, no. 73: «Ego ... Raol de Arrassunna, qui comparo isto orto de te Bonet de Bordel in facie de tua muliere Lucia super nomen Non Mais et de tuos filios et uicinos ... dono tibi in illo .XLaV. solidos Iacensis monete."

22 Ibid.: «Ego tibi illos dedi et tu illos recepisti in facie de totos istos uicinos et testes et auditores." 
transaction, which suggests that the charter was intended to be an accurate record. This purpose is seen most clearly in the scribe's efforts to record the customary procedures of land transactions (which were carried out orally). He documented the all-important fact that the local community and witnesses observed the transaction, thereby approving it. Besides this, the scribe noted that the customary meal called the aliala was eaten, an act in itself that sealed a transaction ${ }^{23}$. The documenting of all these practices suggests that the charter was intended to show that the custom for property transactions had been faithfully observed. This documentation would subsequently establish the validity of the transaction. In this way the written word complemented custom by preserving its memory and by verifying its observance. If this is true, then the charter was clearly intended as a record of the transaction. Charters in Aragonese society were, therefore, records serving as more than witness lists, although this still remained one of their functions.

The circumstances surrounding the redaction of charters in Aragon also evidence uses other than witness lists. When charters were drawn up, they apparently were read both to witnesses and to the seller commissioning the charter. This practice comes across most clearly in a document of 1129. A Durán sold a garden at Tudela to the bishop of Calahorra, Sancho. Through the scribe, Durán noted that «I, Durán, ... ordered this charter to be written, and I have heard [it] read." ${ }^{24}$ Besides this point of business, Durán also "handed [the charter] to the witnesses for the purpose of confirming [it].»" Durán's actions indicate that a scribe drew up a document, which was then read both to the person requesting its redaction and to the witnesses confirming it. That the witnesses confirmed the document indicates their verification of the oral part of the property transaction. Witnesses and document both served to record the transaction; one record was the collective memory of the witnesses, the other written. Aragonese society was probably on the whole nonliterate--after all Durán had the document read, both to himself and probably also to the witnesses. But writing played a role in the oral procedures of this transaction, since the witnesses heard the details of the transaction from the reading of the document and confirmed them ${ }^{26}$.

2" Ibid.: "Comedimus in aliala .V. sol. in pane et uino et carne." On the aliala, see Oliverio NORTES VALLS, Estudio del béxico latino medieval en diplomas aragoneses anteriores a 1157, "Archivo de filología aragonesa», 24-25 (1978), p. 49.

${ }^{24}$ Documentos, no. 178 (1129): «Ego Duran ... ista carta scribere iussi et legere audiui.w Tudela is now in Navarre; at the time of the sale, Tudela was part of the Aragonese realms.

25 Ibid.: "Ad roborandum testibus tradidi."

26 Documentos, no. 222 (1133) suggests that charters were meant to be read. Before the datum, valeat has been written. The word is Latin for goodbye and shows that the reading of the document has ended. 
Other evidence as well demonstrates purposes -especially as records of property transactions- for charters other than witness lists. In the corroboration of a document of 1132, a certain Ala confirmed her donation of property to the cathedral of San Salvador of Zaragoza "just as it is written above." ${ }^{27}$ By this statement, $\mathrm{Ala}$ acknowledged that the document recorded accurately her donation to San Salvador, and that this was its purpose. At least to Ala, the charter functioned as more than a witness list.

A formula used in private charters indicates that property transactions were enacted through documents, suggesting they were dispositive. The formula is per hanc scripturam venditionis. An example of its use comes from 1132, when Altisenes noted that he and his children «through this writing of our sale are sellers." ${ }^{28}$ In another example Pere Çabater and wife Guasen used a similar formula in their sale of property: «Through this writing of sale ... we sold some houses." 29 If this charter formula is taken at face value, then the property transactions had been enacted through charters, making them dispositive.

Examples from other documents suggest that the use of charters ensured the stability of property transactions. In 1087 Galindo, abbot of Santa María of Alquéazar and San Pedro de Estada, exchanged properties with Ondisculo of Araguas, at the order of Pedro Sánchez, future king of Aragón. (At that time he was ruling the counties of Sobrarbe and Ribagorza for his father, King Sancho Ramírez). The prohibitive clause of the document states: "And it is written above, so that [the exchange of property] may be firm and stable for the property of Santa María and San Pedro de Estada." "A donation would seem to have stronger force if written down. As only suggested in this example, the reason for this can be credited to the tangible evidence provided by writing. A charter offered a more stable record of a transaction, since memory could be more fleeting and less stable over time--witnesses could die or move away. The internal evidence of an Aragonese charter has again suggested its use other than as a witness list, the document in this case perhaps even having legal force.

Certain charter formulas do testify to the legal force of charters. The imprecative clauses of many charters linked violations of the transaction with violations of the charter itself. Lady Blasquita of Biniés gave various properties

27 Ibid., no. 214 (1132): «Et ego Ala laudo et confirmo sicut superius scriptum est."

26 Ibid., no. 215 (1132): «Ego Altissenes simul filiis et filias uel filiabus nostris ... per hanc scriptura uinditionis nostre uenditores sumus."

29 Ibid., no. 134 (1126): «Ego Pere Çabater et uxor mea Guasen, per hanc scripturam uendicionis ... uindimus unas casas. $\nsim$

* $\mathrm{CDH}$, no. 52 (1087): «Et superius scriptum est ut sit firmis et stabilis ad proprietate de Sancta Maria et Sancto Petro de Stata.» 
to the monastery of San Pedro of Siresa sometime in either 1114 or 1115 . She observed in a renunciative clause of the charter that «I should not have power to destroy this charter." " A charter from 1119 contains a similar clause concerning the relationship between the charter and transaction. The document records the acquisition of two fields by the clerics of San Pedro el Viejo of Huesca and provided for the safety of the transaction by this warning: «Whoever wishes to violate or to interrupt this charter or donation ... let him accept a part in hell with the traitor Judas and with Dathan and Abiron." ${ }^{32}$ In this case the charter and donation were clearly considered the same--a violation of either threatened the transaction.

In this last example, an attempted violation of the charter meant that the transgressors would be subject to spiritual penalties. Other types of formulaic injunctions against violators of charter and transaction existed as well; these penalties were temporal, rather than spiritual. In 1121 Per Denia sold a garden and vineyard to Raol of Larrasoaña. The imprecative clause of the document made it clear that «if a man or any person signed below ... by force or by any deceit ... wishes to disrupt this charter", then the fidanzas (guarantors) were obligated to protect the transaction by finding another garden for Raol ${ }^{33}$.

This formula, by no means an isolated example, demonstrates that the charter served as a legal record of a property transaction. If the charter were violated, then the customary legal processes were triggered to protect the safety of the transaction -in this case, the fidanzas or guarantors of the transaction acted. Although Per's and Raol's charter did not so state, other charters stipulated that the fidanzas acted according to local custom: «fidanza ... according to the custom of the land" (fidanza ... secundum usum terre), or "fidiatores of security ... just as the custom in Tudela" (fidiatores de saluetate ... sicut est for in Tutela) ". The function of fidanzas illustrates well the combina-

${ }^{31}$ Ibid., no. 118 (1114 or 1115): «Non habeam potestatem destruere itstam cartam."

32 Documentos, no. 61 (1119?): «Quicumque hanc donationem uel cartam irrumpere uel minuere uolerit ... cum Iuda proditore et cum Datan et Abiron in inferno partem accipiat."

"Ibid., no. 72 (1121): "Sunt fidanzas de saluetate Per Miro gener meus et Gerot, in tali conuencione ut si quis homo uel aliqua subrogata persona, excepto rege, per uim aut per aliquo ingenio inter te uolerit trahere et istam cartam uolerit disrumpere, ad laudamento de uicinos in altero tali horto te mittat." For other examples of this formula, see ibid., nos. 73 (1121), 74 (1121), 90 (1123); and $\mathrm{CDH}$, no. 132 (1131).

34 The first example comes from $\mathrm{CDH}$, no. 110 (1112); the second from Documentos, no. 177 (1129). Fidanzas and fidiatores were often used in Aragon and Navarre as guarantors of any type of agreement. Fidanza comes from the vulgar Latin fidantia and classical Latin fidentia, both meaning confidence. Cf. VALLS, p. $\mathbf{5 2 .}$

The fidanza most likely was derived from the fideiussor of classical Roman law, on 
tion of the written word and custom found in Aragonese charters. The legal safeguard of the fidanza was a vital customary practice of Aragonese property transactions; the charter recorded who the fidanzas were and by what authority they acted (secundum usum terre). Once the charter was violated, then the fidanzas acted. Charters thus stood as records of property transactions, thereby giving legal force to charters.

All of these formulas strongly evidence the legal force of the private charter in Aragon and its use as more than a mere witness list, the usual role of the private charter assigned by traditional diplomatics ". The formula discussed above, per hanc scripturam venditionis, indicates that charters using this formula were dispositive, since the transaction was enacted by the document. Rather than overanalyzing various charter formulas and groping for clues about their legal significance, the matter of the dispositive force of private charters could be easily resolved if a charter were clearly used as the only means of transferring property. Such a document is unfortunately lacking. Even the documents with the formula per hanc scripturam venditionis include witness lists and fidanzas, indicating that they recorded an oral transaction. The transaction itself also had the legal force of transferring property, not the document alone. We must remember that property transactions were oral proceedings, enacted before the local community, whose presence stamped the proceedings with legality ${ }^{36}$. Nonetheless, charters had some type of legal force, as the formulas discussed above most assuredly demonstrate. This legal stature perhaps came from the approval of property transactions (which charters represented) by the local community. Because of its approval, the local community indirectly validated the charter that recorded the transaction. In this way, the public notary that reappeared in Aragon in the thirteenth century was not needed to legitimize charters. The custom of the community did so and functioned in place of

whose function, see Adolf BERGER, Encyclopae dic Dictionary of Roman Law, "Transactions of the American Philosophical Society», n.s., 43, pt. 2, Philadelphia, 1953, pp. 350-1.

The word fuero here undoubtedly has the sense of custom, not of codified municipal law. See Jesús Lalinde Abadía, Los Fueros de Aragón, 4th ed., Colección "Aragón," 1, Zaragoza, 1985, pp. 12-13. The fuero of Tudela states that the fidanza should be chosen according to the fuero of a locality but elaborates no further than this: «Date ei fidanza de directo, sicut est vestro fuero. "See Colección de fueros municipales y cartas pueblas de los reinos de Castilla, León, corona de Aragón y Navarra coordinada y anotada, ed. Tomás MUÑOZ y ROMERO, 1, Madrid, 1847; reprint ed. Madrid, 1970, p. 421.

"For this traditional view, see ALONSO, pp. 391-2. Bono believes, however, that all documents of this type were dispositive; see his Historia, I:1, p. 139. On the reinterpretation of the charter's function in the early Middle Ages as more than a witness list, see McKitterick in $\mathbf{n}$. 5 .

36 Alonso, pp. 391-2. 
public authority. Customary practices could have a force, then, that was for all intents and purposes public.

Although not a charter, the will of Lop Garcés Peregrino, one of Aragon's most powerful lords during the reign of Alfonso the Battler, provides a solid example of the legal role of the written word in judicial matters. Lord of such places as El Castellar and Alagón for the Battler, Lop amassed a great fortune of land and property, probably through his participation in the Aragonese Reconquista. Along with his wife Maria, he bequeathed this fortune to the Templars, Hospitallers, and the church of Santa María of Zaragoza, in a will drawn up either in 1133 or $1134^{37}$.

Perhaps in 1148, the date is uncertain, García Romeu and his brother disputed the will for reasons unknown. The Templars, and the canons and bishop of Zaragoza defended themselves against the Romeu clan before the court (plena curia) of Ramon Berenguer IV, count of Catalunya and prince of Aragon, and his justiciar (Ato Sans, iusticia). The defense of the ecclesiastics rested on the testimony of two of the witnesses of Lop's will, whose purpose was to authenticate the will: «the witnesses swore that they saw and heard that lord Lop Garcés so made his testament just as it is written in the foresaid charter. ${ }^{38}$ The written word in the form of Lop's testament had been introduced before the count's court, so that the witnesses of Lop's will could be produced and authenticate the document. The will obviously had some legal force ${ }^{39}$, since it was introduced into the hearing as evidence. The purpose of the witnesses' testimony was to confirm that they had seen and heard Lop make his will as recorded in the document. Oral testimony validated the document; but the written word evidenced whether or not Lop's will had been carried out properly. In this case, the written word complemented custom, helping to establish a legal decision. Lop's purposes in drawing up the will had been fulfilled--the written word had protected the disposition of his property.

Both the great nobility and lesser folk of Aragon commonly used charters for the business of property transactions. No seignorial archives have survived from the great nobility of Aragon ", apparently creating difficulty in proving

37 The will is found in Documentos, no. 230 (1133 or 1134). A list of Lop's lordships can be found in Agustín UBIETO ARTETA, Los atenentess en Aragón y Navarra en los siglos Xl y XII, Valencia, 1973, p. 245.

38 Documentos, no. 354 (1148?): «Episcopus et canonici Sancti Saluatoris et illi etiam de Hospitali darent duos testes de illis qui sunt scripti in predicta carta, qui iurarent quod ipsi uiderunt et audierunt quod senior Lop Garcez sic fecit suo destinamento sicut est scriptum in prefata carta."

39 Alonso, p. 391.

40 José María LACARra, La Reconquista y repoblación del Valle del Ebro, in *La reconquista española y la repoblación del país», eds. José María FONT RıUS et alii, «Escuela dc Estudios Medievales», 15, Zaragoza, 1951, pp. 47-48. 
that the nobility regularly used documents. The cause is not lost, however; documents of the great nobility of Aragon can be pieced together from such sources as monastic cartularies. In this way the great nobility's use of charters as a matter of course can be demonstrated. The best example of this use comes from the career of the greatest noble of Alfonso the Battler's reign, Fortún Garcés Caxal.

Charles Julian Bishko has studied most thoroughly the reign of this great Aragonese lord ${ }^{4}$. Bishko has shown that Fortún received from Alfonso I generous grants of individual properties and lordships over such places as Daroca and Tudela. Through private acquisitions of property Fortún expanded these holdings created by royal largesse. For example, in 1127 Fortún and his wife Tota bought various properties around Tudela from Muslims. In 1130 or 1131 the couple added to their patrimony by purchasing property at Uli in Navarre ${ }^{42}$, in the interior of Alfonso's realms. In these personal acquisitions of property, Fortún and Tota seem to have relied on the written word to conduct their affairs; oral custom and the memory of witnesses were not the sole Caxal means of conducting business. The couple perhaps needed the written word, because, as Bishko has pointed out, their holdings were scattered throughout the Ebro River Valley and also located in the interior of Navarre. To manage them better, written records were useful. Besides relying on the written word to buy property, Fortún and Tota disposed of their property in various wills and also granted property through charters ${ }^{43}$.

Fortún's case is not isolated. Lop Garcés Peregrino, whom we have already met, was another important Aragonese nobleman who used the written word for property acquisitions. As with Fortún and Tota, Lop's and his wife Mayor's private charters can be gleaned from edited documentary collections, shedding some light on the couple's use of the written word. In 1132 he purchased some property at a village called Azohor; in that year he also exchanged fields with a Jew in the Gallego River district above Zaragoza. In 1133 Lop and Mayor built and donated the church of San Nicolás of Zaragoza to the cathedral of La Seo in Zaragoza. And, as we have seen, Lop and Mayor had their will drawn up ".

4 Charles Julian BISHKO, A Hispano-Cluniac Benefactor in the Epoch of NavarroAragonese Separation: Fortún Garcés Cajal and the Founding of San Adrian of Vadoluengo (Sangüesa), 1133-1145, in «Estudios en homenaje a Don Claudio Sánchez- Albornoz en sus 90 añosw, 2 vols., Buenos Aires, 1983, 2: pp. 275-312.

${ }^{42}$ For the holdings at Uli and Tudela, see BISHKO, pp. 285-9. The charters can be found in their edited form in Documentos, nos. 139 (1127), 198-200 (1130-1131).

43 For the will, see ibid., no. 226 (1133); for the grant of property, see no. 222 (1133).

4 For the charters, consult Documentos, nos. 215 (1132), 216 (1132), 227 (1133), 230 (1133 or 1134$)$. 
Lop probably did not issue the charters recording his purchases in 1132 . For the property at Azohor, the seller had the document drawn up: «Altisenes ... with our children, who ordered this charter to be written." "' The document recording the purchase of property in the Gallego district is unclear about who had the document drawn up; but Lop's charter of donation of the church of San Nicolás is clear: «Peter of Zaragoza, canon, by the order of lord Lop Garcés and his wife, with the counsel of all the canons and all the residents, wrote this charter.» ${ }^{46}$ These examples attest to Lop's use of the written word in personal business matters. Even if he did not have all the charters just discussed drawn up, Lop did defer, nevertheless, to the preference of others in using the written word. This would suggest that he believed the use of charters a normal way to conduct business. Nor should it be overlooked that Lop had documents drawn up at his own request. If their example is any indication, then Lop and Fortún suggest that the great nobility of Aragon were not unaccustomed to using the written word.

Lop's and Fortún's use of the written word does not yield evidence on the existence of private chanceries among the nobility. As was probably the practice of the Aragonese ${ }^{47}$, the two great lords and their wives relied on private scribes for the redaction of documents. If unfruitful in determining the possibilities of private chanceries, Lop's example does provide fresh evidence about where Aragonese nobles stored their documents. Copies of his will were given to the church of Santa María of Zaragoza and to two of the witnesses: "Fortún Aznaréz gave that charter of testament ... to lord Vilelmo, chaplain of Santa María, and Fortún Blaschez and Garnero, witnesses." ${ }^{48}$ According to this example, private documents could be stored with ecclesiastical institutions and witnesses for safekeeping. Churches and monasteries probably served as the most important local depositories for documents.

The storing of documents with witnesses may have had another purpose than the safekeeping of documents. Witnesses could use documents in their possession to verify a transaction; thus, they did not have to rely solely on memory. Witnesses also functioned as more than a way of verifying transactions: they were record keepers who preserved transactions by their memories and by the documents in their possession.

4" Ibid., no. 215: "Altisenes et filiis nostris qui ista carta mandauimus scribere."

46 Ibid., no. 227: "Petrus Cesarauguste canonicus iussione de senior Lop Arceç et eius mulier et cum consilio omnium canonicorum et omnium uicinorum hanc cartam scripsit."

47 BonO, I:1, p. 115.

4 Documentos, no. 230 (1133 or 1134): «Dedit Fortun Acenarz illa carta de illo testamento quod fecit senior Lop Garcez Pelegrino ad domno Vilelmo capellano de Sancta Maria, et Fortun Blaschez et Garnero, testes.» 
If the use of charters appears commonplace among the nobility, then neither did the lesser folk of Aragon differ in this respect. Examples of charter use among them abound. A typical instance can be found in the sale of some houses and a shop in Zaragoza by Pere Çabater and wife Guasen to Iñigo Galíndez ${ }^{49}$. The scribe redacted the document at Pere's and Guasen's order, as the corroboration demonstrates: «Pere Çabater and my wife who ordered this charter to be written.»" That the couple ordered the document drawn up indicates the use of the written word was not foreign to them.

Internal evidence from this document suggests the social status of the transaction's participants. The format of this document is similar to the others that we have studied: notification, disposition, witness list, and list of fidanzas. The names gleaned from these different parts of the charter evidence their social status. Neither buyer, seller, witnesses, nor fidanzas bear the title of señor, don, dominus, dompnus, or dompna, all words used in Aragonese charters denoting noble status. The lack of titles suggests that the participants in the transaction were commoners or, at best, infanzones, the lesser nobility of Aragon. Since the persons of this charter lack titles, perhaps the more plausible interpretation of their social status is that of commoner. Also Pere bears the surname of Çabater, which transliterates into the modern Castilian word for shoemaker, zapatero. This surname suggests that Pere's occupation was shoemaker, a profession not highly pursued by the nobility of the Middle Ages. It appears as if the participants in this transaction such as Pere, Guasen, and Iñigo were commoners, and that they accepted the use of writing in property transactions.

Other documents also bear out the use of charters among commoners and the lesser nobility of Aragon. In 1124 Roberto bought a shop in Zaragoza from Guiomar and his wife. The scribe attributed no titles of nobility to any of the participants in the sale, whether buyer, seller, witnesses, or fidanzas ". The participants were probably merchants, as evidence from the document itself suggests. Witnesses of property transactions usually came from the locale in which the property was located; the place of this transaction was probably a shopkeeper's district. One witness to this transaction was «Randulfus zabaterius," suggesting that his occupation was shoemaker. Furthermore, the shop bought by Roberto was in a neighborhood of alfondas or caravansaries for traveling merchants ". These facts indicate that the participants in this transac-

4) Ibid., no. 134 (1126).

"Ibid.: "Pere Çabater et uxor mea Guasen, qui ista carta mandauimus scribere."

"lbid., no. 95 (1124).

"I Ibid.: «Et [est] illa tenda infra alfonda de Garner carnifice de Osca, et infra alteram alfondam de Galter lo corner de Osca ... Huius rei sunt testes ... Randulfus zabaterius." 
tion were craftsmen and shopkeepers. If so, then one could conclude that such people in places like Zaragoza used charters for property purchases.

In 1123 Raol of Larrasoaña, whom we have met previously, bought a field in the Gallego River district above Zaragoza from Benedict of Bolea and his wife. As with the previous examples, the witnesses, fidanzas, sellers, and buyer all lack titles of nobility". In fact, Raol appears in a number of documents as a buyer of property around Zaragoza, and he is never given the title of lord ${ }^{34}$. Raol was perhaps a commoner, a well-to-do landowning peasant who used charters for his land transactions at Zaragoza. His example seems to be the rule rather than the exception in the countryside around Zaragoza, where the charter was commonly used in property transactions".

For some of Raol's purchases, nobles served as witnesses and as fidanzas. In 1121 Raol bought from a Don Ponç four fields. Ponç, whose title Don suggests noble status was also called a sporoner, a maker of spurs, revealing that all trades were not confined to commoners ". Because of Don Ponç's involvement in a trade, perhaps he was an infanzón. The witness list describes one witness as "Don Helias,» suggesting that he too was noble. This mixture of noble and non-noble in this charter reveals that persons of different degrees of social rank participated in purchases of land, and that both used the written word to record transactions". In a matter of the utmost importance for an agrarian society--the alienation of land-- the written word in the form of the charter played a vital role. Probably not all business important in an agrarian society was conducted by the written word. Inheritable property, for example, probably did not pass to heirs through documents, since the customary right of

"Ibid., no. 93 (1123).

'4 For Raol's purchases, see the appropriate notes above and also Documentos, nos. 72 (1121), 74 (1121), 78 (1121), 90 (1123).

"For other examples, see Documentos, nos. 71 (1120), 78 (1121), 83 (1122), 90 (1123), 95 (1124), 99 (1124), 100 (1124), 114 (1125), 129 (1126), 140 (1127), 163 (1128), 179(1129), 193 (1130). For Tudela, see nos. 108 (1124), 118 (1125), 177 (1129), 178 (1129).

"Documentos, no. 74 (1121): "Comparaui adhuc ego Raol de Larussunna de don Ponz sporonero III. campos in Aliafaria et de uno campo quod est in Orba." On the sporoner, see NORTES VALLS, p. 124.

"Compare this use of charters in Aragon in the late eleventh and early twelfth centuries to conclusions about England reached by M. M CLANCHY, From Memory to Written Record: England, 1066-1307, Cambridge, Massachusetts, 1979, pp. 53-7, 209. He believes that before 1200 properties were normally given without documentation. Influenced by the practices of the English monarchy, the great barons of England had adopted the use of documents by 1200; by 1250 knights were using documents; and by 1300 documents were used even in property transactions between peasants. The use of the written word in Aragon seems to have prevailed earlier than in England. 
ius bereditas already ensured inheritance. In the alienation of land between two different parties, though, the use of charters was the rule. In this way, the written word performed an important function for the agrarian society of Aragon.

This brief examination of private documents has suggested that their use was common in property transactions in Aragon. The case was equally true--in fact, even more so--for the Aragonese monarchy. The large number of royal charters granting land shows that the written word was the usual way for Aragonese kings to reward the faithful participants of the Reconquista. To colonize lands after conquest from Muslims, the normal procedure for kings was to give and authorize grants through charters. Examples of the use of charters from the reigns of Pedro I and Alfonso the Battler will demonstrate this function, as well as other uses.

In 1098 Pedro I granted to Fortún Garcés properties in Huesca that had been owned by a Muslim. Displaying a form similar to private charters, the charter opens with an explicit invocation, which is followed in the notification by Pedro's description of the grant as a donation ${ }^{88}$. Land grants such as these belong to the category of royal privileges ", according to Angel Canellas López who worked out a typology for royal charters in his study of the Aragonese royal chancery before the union with Catalunya.

After the disposition in the corpus, Pedro, through the scribe, noted in the renunciative clause that «this donation that is written above ... you should have it secure and free, noble and free ... as your own alod ... except for my loyalty. $"{ }^{60}$ The king himself assured the validity and security of the grant; no fidanzas or witnesses were needed to secure or to authenticate the transaction. This royal charter was dispositive, made sure by the king's own authority. After the renunciative clause, the signum of the king, and the actum and date follow, along with a list of important personages of the realm.

The common format of royal charters from the reigns of Pedro and Alfonso strongly evidences continuity in royal chancery practices. The example of Alfonso's grant to Guillermo Sánchez of Tena will suffice to demonstrate the similarity. As always, an Aragonese royal charter begins with an explicit invocation in the initial protocol, followed by the notification (facio banc cartam donacionis) ". Next, a long disposition outlines Guillermo's good fortu-

- CDH, no. 72 (1098): «Facio hanc cartam donationis."

9 Ángel CANELlas LOPEZ, La cancillería real del reino de Aragón (1035-1134), in «Folia budapestina», Publicación número 900 de la Institución «Fernando el Católico», Zaragoza, 1983, p. 29. This work is undoubtedly the final word on its subject.

60 $\mathrm{CDH}$, no. 72: «Hoc donativum quod superius est scriptum ... habeas eum salvum et liberum ingenuum et franchum ... salva mea fidelitate."

61 Colección diplomática de Alfonso I de Aragón y Pamplona (1104-1134), ed. José Angel Lema Pueyo, Fuentes Documentales Medievales del País Vasco, 27, San Sebastián, 1990, no. 126. Hereafter cited as CDA. Compare this notification to Pedro's in n. $\mathbf{5 8 .}$ 
ne, for the Battler had rewarded Guillermo handsomely with title to various properties in a village called Bascués. Alfonso states that «this whole donation, just as it is written above ... you should have it as your own property ... except for my loyalty and of my descendants." "62 The final protocol concludes with the signum of the king, actum, date, and a list of important personages of the realm. The form of the charter follows closely that of royal charters from Pedro's reign; and examples of this similarity could be multiplied many times.

As in many royal charters, a key formula is «sicut superius scriptum est» (just as it is written above). The phrase suggests that the wording of a document was intended to be precise. Perhaps this formula could be discounted as only a routine clause, notable only for its frequent use; but evidence suggests otherwise. Precisely outlined in their wording, royal documents contained important legal rights over property. This comes to light in a remarkable document from 1118.

Iñigo Sanz of Laves and family had been kidnapped by Muslims from their home at Ayera in 1112. Iñigo's captivity was not easy; he was imprisoned six years in Muslim lands, suffering «in chains ... and they tortured us by hunger and thirst." ${ }^{63}$ Iñigo's captivity did not end until 1118, when the Aragonese lord Fortún Dat ransomed him. The happiness of Iñigo's rescue was darkened by his obligation to repay the costs of his ransom to Fortún. Unable to find help from friends or family, this unfortunate man turned to the monks of San Pedro el Viejo of Huesca, to obtain the needed money. They were willing to buy Iñigo's land near Ayera, thus providing him with the ransom money ${ }^{64}$.

Iñigo, however, lacked a charter proving his ownership of the land and subsequent rights to alienate it. The monks consequently refused to do business with him, until he produced such a charter: «the monks said to me that they would give to me one thousand solidi of Jacan money for my property of Ayera ... if I might be able to have a charter from my lord king Alfonso, by whose license I might be able to sell and they themselves able to buy.»"

62 Ibid.: «Hoc totum donatiuum, sicut superius scriptum est ... habeatis illud ingenuum et liberum et francum ad uestram propriam hereditatem ... salua mea fidelitate et de omni mea posteritate."

or Documentos, no. 53 (1118): «Ego Enecho Sanc de Laues ... fui captiuatis in Aiera cum uxore mea et filio et filia ... miserunt in carcerem in cathenas, et cruciauerunt nos fame et siti.w It has been suggested that Iñigo's capture at Ayera resulted from a raid through Christian Aragon in 1112 by the Murabitun, the Sanhaja Berbers ruling Islamic Spain. On the raid, see Antonio UBIETO ARTETA, Historia de Aragón. La formación territorial, Zaragoza, 1981, pp. 146-7.

of Documentos, no. 53: «Et quando fui solitus non inueni consilium nec cum aliquo parente nec cum aliquo homine uel femina.»

6s Ibid.: "Dixerunt mihi quod darent mihi pro hereditate mea d'Aiera mille solidos 
Desperate, Iñigo rode to Zaragoza, where Alfonso was besieging the city, to obtain a charter; this the former captive successfully accomplished ${ }^{66}$. Iñigo's possession of a charter meant that the monks would now buy his property. After Iñigo showed the document to the monks of San Pedro, «they saw the charter from the part of the king that made it licit to sell my property and for them to buy, they gave one thousand solidi to men. ${ }^{67}$

As this document shows, royal charters empowered those receiving land grants with indispensable rights of ownership. The wording of the document was also important, for it described these rights. In Iñigo's case, a «charter of nobility and liberty" (kartam ingenuitatis et libertatis) confirmed his rights of ownership over his property. The written word established legal rights over land, not custom. Not until the monks saw Iñigo's charter would they buy his land. Royal charters stood as legal records of property transactions, that gave to their holders rights over property.

The Aragonese relied on another type of royal document, the albara, to alienate property. Albara is an obvious transliteration of an Arabic word, as shown by its Arabic root $b r^{\prime}$, meaning release or exemption ${ }^{68}$. In the Islamic world bar'a denoted written documents; for example, in eighth century Iraq bar'a meant a receipt for the payment of taxes. "

Albara still survives in modern Castilian, Catalan, and Portuguese with the same sense of receipt. How the word came to be used by the royal scribes of Aragonese kings is, of course, a mystery. Its general adoption throughout the Christian Iberian Peninsula is an interesting case of acculturation that suggests a hole in Christian vocabulary that only bar'a could fill. In Aragonese royal documents albara retained its sense of receipt, usually for property. The earliest usage of albara that this author could find comes from the reign of Pedro I. In 1098 he declared in the notification of a charter that «I, Pedro Sánchez, ... make this albara to you, Lope Fortuñones. ${ }^{71} \mathrm{~A}$ list of properties given to Lope

\footnotetext{
Iaccensis monete ... si cartam possem habere de domno meo rege Anfusso, cuius licencia ego possem uendere et ipsi possent emere."

6 Ibid.: «Equitaui ... ad domnum meum regem ad Cesar Augustam ... [Alfonso] fecit mihi kartam ingenuitatis et libertatis ut uenderem.»

6) Ibid.: «Ipsi quando uiderunt kartam ex parte regis quod mihi liceret uendere ereditatem meam et illis comparare, dederunt mihi mille solidos."

On these points, see NORTES VAlLS, pp. 236-7; and Bara'a, in «Encyclopaedia of Islam», 2nd ed. rev., Leiden, $1960 \mathrm{ff}, 1:$ p. 1026.

69 Ibid., and Michael MORONY, Iraq after the Muslim Conquest, Princeton, New Jersey, 1984, p. 115.

70 Colección diplomática de Pedro 1, ed. Antonio Ubieto ARTeta, Escuela de Estudios Medievales, Textos: 19, Zaragoza, 1951, no. 44 (1098): «Ego Petrus Sangiz ... facio hanc albara ad te, Lope Fortuniones." Pedro I often signed his documents in Arabic; Ubieto (p. 19) suggests that this was done to prevent falsification of royal charters.
} 
follows this declaration. The albara in this context seems to have functioned as a receipt.

The document is unusual, since documents actually called albaras are extremely rare. The albara was usually only referred to in other documents, themselves not albaras. In one example, a document of Alfonso spoke of his officials who distributed albaras ". Since Alfonso was confirming land grants authorized by his officials, the albara seems to have been a document through which grants were made. If so, it probably played an important role in the royal settlement of such places as Zaragoza.

Once given, the albara was not forgotten by its recipients; individuals often referred to their albaras as giving them right to alienate property. In 1124 Sancho Garcés and wife Toda sold to Bernard and Señor a garden that "we have from our right albara." "In 1126 Aznar Arcés and family sold to Hugo and family a field: «It the field came to us from settlement and with our own albara." "' In a document previously discussed, Altisenes sold to Lop Garcés Peregrino property that had come to Altisenes «from the donation of our lord king and from our albara." ${ }^{74}$ That these three examples of the albara come from Zaragoza or its environs also demonstrates the albara's use in settling the area.

The individual sellers in these three documents at least partly established their rights to property by the albara. The use of the albara in this manner meant that the written word was relied on to prove property rights, and that customary means of determining property ownership, especially the use of witnesses, were superseded. Reference to the albara also illustrates the dispositive nature of royal documents, since royal documents alone transferred property. Finally, the albara's use in private property transfers again evidences the reliance on the written word in the private sphere of Aragonese society.

This examination of charters and the written word has shown that the written word was no stranger even in a customary society like Aragon. Charters served as records of the oral custom by which transactions were conducted, were

" CDA, no. 261 (1133): «Aldefonsus ... mando et concedo et confirmo ad vos totos populatores de Caragoça ... totas vestras hereditates quod habetis in Caragoşa ... quod vobis dederunt meos partitores de albaras ... totas illas habeatis liberas.»

12 Documentos, no. 99 (1124): «Ego Santio Garcez et mea uxor Tota et omnes mei filii et filie uendimus uobis Bernardo et Seniori ... unum ortum ... que habemus de nostra recte albara.n

"Ibid., no. 129 (1126): «Ego Acenar Arcez et uxor mea Duanoro simul filiis uel filiabus nostris, uobis emptoribus nostris Huc et uxor uestra Petronella simul filiis uel filiabus uestris ... uno campo ... aduenit nobis de populatione et cum nostra albara.»

${ }^{4}$ Ibid., no. 215 (1132): «Illo naucio ... qui nobis aduenit de donatione de domno nostro rex et de nostra albara.» I have not been able to determine what a naucio is; the context of the document suggests that it is some type of property. 
commonly employed on all levels of Aragonese society, and had legal force. Royal charters were the common means by which kings made grants from their patrimony, and recipients of royal charters relied on them to enjoy rights of possession over land. Through such usages, the written word in the form of the charter functioned vigorously in Aragonese society by complementing custom in private property transactions, and in the case of royal charters, by superseding custom. Indeed, the charter was used in Aragon as a chief means of establishing legal and social ties in such vital matters in an agrarian society as the holding of property.

\section{RÉSUMÉ}

Le Royaume d'Aragon offre une excellente possibilité d'étudier les écrits dans la société quotidienne médiévale. Et ceci, parce que les aragonais, pendant les règnes de Pedro I (1094-1104) et d'Alfonso I (1104-1134) conquirent de nombreux territoires, créant un important marché dans lequel les écrits, sous forme de chartes, étaient le moyen le plus courant pour aliéner des propriétés. Les chartes étaient communément utilisées à tous les niveaux de la société, par les rois, la noblesse et les roturiers. Les chartes privées avaient force de loi et représentaient l'enregistrement des transactions, de même que les coutumes orales par lesquelles les transactions étaient menées. Elles servaient, par conséquent, plus que comme simple témoignage, qui est le rôle qui leur est généralement attribué par les diplomates habituels.

Les chartes royales étaient le moyen commun par lequel les rois octroyaient la terre, et les destinataires des chartes royales comptaient sur elles pour jouir de leur droit de propriété. $\lambda$ travers les usages des chartes royales et privées, les écrits faisaient autorité en suivant la coutume au moment des transferts des propriétés privées, et, dans le cas des chartes royales, en supplantant la coutume. La charte fonctionnait en Aragon comme moyen principal dans l'établissement légal et social d'attaches dans un domaine aussi vital pour une société agraire comme la jouissance de la propriété.

\section{SUMMARY}

The kingdom of Aragon offers an excellent opportunity to study the written word in a medieval, customary society. This is so because the Aragonese during the reigns of Pedro I (1094-1104) and Alfonso I (1104-1134) conquered much territory, creating a great landmarket in which the written word in the form of the charter was the normal means to alienate property. Charters were commonly used on all levels of society by king, nobility, and commoner. Private charters possessed legal force and were records of transactions, including the oral custom by which transac- 
tions were conducted. They thus served as more than mere witness lists, the usual role assigned to them by traditional diplomatics.

Royal charters were the common means by which kings granted land, and the recipients of royal charters relied on them to enjoy property rights. Through such uses of private and royal charters, the written word functioned vigorously by complementing custom in private property transfers, and in the case of royal charters, superseding custom. The charter functioned in Aragon as a chief means of establishing legal and social ties in such vital matters in an agrarian society as the holding of property. 